\title{
The institutional vs. the academic definition of the quality of work life. What is the focus of the European Commission?*
}

Vicente Royuela, Jordi López-Tamayo and Jordi Suriñach

AQR-IREA Research Group, University of Barcelona

690 Av. Diagonal, 08034, Barcelona, Spain

Email:vroyuela@ub.edu,jlt_lopez@ub.edu, jsurinach@ub.edu. Fax:

+34934021821

\begin{abstract}
In recent years, we have seen how the quality of work life has been focused and defined by the European Commission (EC). In our study we compare the EC definition with the academic one and try to see how close they are. We also analyse the possibility of applying the institutional definition to the Spanish case through the development of specific indicators. Our main conclusions are that QWL is increasingly important for policy makers. In addition, it is essential to have objective indicators and to conduct surveys in order to reliably measure QWL.
\end{abstract}

\footnotetext{
* The results presented in this study were obtained within the framework of the project "Estudio Manpower Professional. Calidad Laboral”, funded by Manpower Professional. Of course, any errors are our own.
} 


\section{INTRODUCTION}

Recent papers (Marcel and Dupuis, 2006) have tried to give a consensus definition of quality of work life (QWL) and a clear way of computing it. This has been achieved by analysing the theoretical perspectives in the literature, in order to achieve a clear outline of how to include all possible dimensions of the concept.

In Dupuis et al. (2000), a general definition of quality of life (QOL) is given: "QOL, at a given time, is a state that corresponds to the level attained by a person in the pursuit of her hierarchically organised goals” (p. 107). Later on, Marcel and Dupuis (2006) take this systemic definition and apply it to QWL. They propose using a questionnaire of 33 domains to give an overall definition of QWL. These domains are linked to the four major dimensions of Turcotte (1988) and the 14 domains of Kohl and Shooler (1982). The academic literature also develops a key concept: effectiveness in work roles. Seashore (1975) states that there are three separate aspects of work: those related to the employer, the employee, and the community. Of course, the goals of each aspect may be different, which may even result in incompatible objectives.

This sound academic definition of QWL can be compared to an institutional definition. Specifically, we refer to the institutional approach that is being developed in the European Union (EU) under the general framework of the Lisbon Strategy.

The aim of our paper is to review the institutional approach and to link it to the academic framework. In particular, we compare the dimensions and look at the work roles that are being considered. We also analyse the possibility of applying the institutional definition to the Spanish case through the development of specific indicators.

In the following section, we describe the EC's institutional approach. We then compare this definition with academic definitions. Finally, we propose indicators that embrace both definitions. A conclusion is given in the final section.

\section{THE EUROPEAN INSTITUTIONAL APROACH TO THE CONCEPT OF QWL}

The Lisbon Strategy aims to deal with changes brought about by globalization and a knowledge-driven economy by defining a new strategic goal. This framework requires an overall strategy that can be broken down into specific objectives and ways of achieving them. In 2000, the Lisbon European Council decided to launch a ten year strategy focused on attaining a leading economic position in terms of dynamism and competitiveness. This strategy is based on four axes: (a) reaching a knowledge-based economy; (b) modernising the European social model; (c) developing a framework of appropriate and stability-oriented macroeconomic policies; (d) achieving sustainable development.

In March 2005 the European Council was held in Brussels. At this meeting, there was significant interest in an intermediate revision of the Lisbon Strategy, as several of the agenda's goals had clearly not been met. These goals included some very interesting specific objectives. Three objectives that are linked to our study are listed below: 
- $\quad$ More and better jobs for Europe: developing an active employment policy. Four areas were associated with reducing unemployment and increasing the employment rate: improving employability and reducing skill gaps; increasing adaptability through lifelong learning; increasing employment in services; and reducing occupational segregation.

- Education and training for living and working in the knowledge society. Europe's education and training systems have to offer learning and training opportunities for the knowledge society through three main factors: developing local learning centres; promoting new basic skills; and increasing the transparency of qualifications. There are also some specific targets: halving the proportion of 18 to 24 year olds with only secondary level education; making schools into multi-purpose local learning centres; introducing a European diploma for basic Information Technology skills; promoting the mobility of education agents; introducing a common format for curricula vitae.

- Promoting social inclusion. The new knowledge-based society has the potential to reduce poverty. However, it also increases the risk of social exclusion. Several steps are recommended to reduce the gap: promote a better understanding of social exclusion; promote inclusion nationally, which is complemented at the community level by the Structural Funds framework; develop priority actions for specific target groups (minorities, the disabled, etc.).

At the Lisbon Special European Council, held in March 2000, it was determined that progress made towards achieving the strategic goal for the next decade - "to become the most competitive and dynamic knowledge-based economy in the world capable of sustainable economic growth with more and better jobs and greater social cohesion" needed to be regularly discussed and assessed. Therefore, the Council invited the Commission to draft an annual synthesis report (the Spring Report) on this progress, using mutually accepted structural indicators. These indicators ensure that the reports are coherent and have a standard presentation.

To meet the European Council's request, since 2000 the Commission has presented a communication at the end of each year, titled "Structural Indicators". This document includes a set of indicators to be used in the synthesis report for the respective Spring European Council (COM-2000 594 final, COM-2001 619 final, COM-2002 551 final and COM-2003 585 final). It is difficult to provide a clear idea of progress towards the Lisbon European Council objectives (expanded at the Gothenburg meeting and refined at the Stockholm and Barcelona councils) when a high number of indicators are used. Therefore, in the 2004 Report from the Commission to the Spring European Council, the list was reduced to 14 structural indicators. This is a very short list, considering that initially there were 42 structural indicators ${ }^{1}$ ( 7 indicators for each domain and 7 general economic background indicators). The final 14 indicators include two that are strictly related to employment: Employment rate and Employment rate of older workers. Additionally, a new list of indicators was considered in the 2003 Communication (COM-2003 585 final). One concept arises in the Employment dimension of this list: Quality of Work. This appears along with vacancies, poverty trap (marginal effective tax rate) and childcare facilities.

Several questions arise in relation to this concept: what does the EU understand by QWL? In what sense do we have to look at this concept? Can it be summarised? In order to answer these questions, we need to refer to the communication from the

\footnotetext{
${ }^{1}$ There was a total of 107 indicators if we count subsections and subindicators.
} 
Commission to the Council, the European Parliament, the Economic and Social Committee and the Committee of the Regions titled: 'Employment and social policies: $a$ framework for investing in quality' (COM-2001 313 final):

'Quality is at the heart of the European social model. It is a key element in promoting employment in a competitive and inclusive knowledge economy. Quality reflects the desire, not just to defend minimum standards, but to promote rising standards and ensure a more equitable sharing of progress. It delivers results - embracing the economy, the workplace, the home, society at large. It links the dual goals of competitiveness and cohesion in a sustainable way, with clear economic benefits flowing from investing in people and strong, supportive, social systems'

This communication is based on the Social Policy Agenda, and defines QWL - better jobs - by looking at both the existence of paid employment and the characteristics of the employment. It is a relative, multidimensional concept. In its broadest definition, it involves taking into account:

- objective characteristics of employment, including the wider work environment and the specific characteristics of the job

- worker characteristics - the characteristics the employee brings to the job

- the match between worker characteristics and job requirements

- the subjective evaluation (job satisfaction) of these characteristics by the individual worker

They assume that there is no standard or agreed definition of quality of work life in the academic and expert literature. Most studies adopt and suggest various key dimensions of job quality. These frequently include a focus on both the specific characteristics of the job (e.g. pay, hours of work, skill requirements, job content) and on aspects of the wider work environment (e.g. working conditions, training, career prospects, health insurance cover etc). However, in light of the Social Policy Agenda and the Lisbon Strategy objectives, a greater consensus is needed on the main elements of quality of work. To provide a framework of analysis, the main aspects of quality of work were grouped under two broad axes: job characteristics and the wider work and labour market context.

However, to address quality of work in a full, coherent and structured manner, an appropriate set of indicators needed to be established within a framework based on consensus. The Commission therefore proposed a set of indicators covering 10 main dimensions of quality within two broad axes. Every dimension was approximated using a set of possible concepts and indicators (see Table 1).

Table 1. EC dimensions of QWL

\begin{tabular}{|l|}
\hline 1. Intrinsic job quality \\
\hline 2. Skills, life-long learning and career development \\
\hline 3. Gender equality \\
\hline 4. Health and safety at work \\
\hline 5. Flexibility and security \\
\hline 6. Inclusion and access to the labour market \\
\hline 7. Work organisation and work-life balance \\
\hline
\end{tabular}




\begin{tabular}{|l|}
\hline 8. Social dialogue and worker involvement \\
\hline 9. Diversity and non-discrimination \\
\hline 10. Overall work performance \\
\hline Source: COM-2001 313 final
\end{tabular}

\section{COMPARING THE ACADEMIC AND THE INSTITUTIONAL APPROXIMATIONS}

Table 2 displays the 10 EC-QWL dimensions and proposed indicators (fourth and fifth columns respectively) used to define QWL. They are grouped, when possible, with the four Turcotte categories (Turcotte, 1988) (first column), the 33 Martel and Dupuis (2006) QWL domains (second column), and the 14 Kohl and Shooler (1982) dimensions (third column). The purpose of our paper is not to review the academic literature, as this has already been done in Martel and Dupuis (2006). Consequently, we only focus on similarities to, and differences from, what we have labelled as the institutional approach, which is that of the EC. 
TABLE 2. Quality of work life dimensions, components, and indicators

\begin{tabular}{|c|c|c|c|c|}
\hline $\begin{array}{l}\text { Quality of work life according } \\
\text { to Turcotte (1988) }\end{array}$ & $\begin{array}{l}\text { The } 33 \text { QWLSI domains (Martel } \\
\text { and Dupuis, 2006) }\end{array}$ & $\begin{array}{l}\text { Work structures (Kohl } \\
\text { and Shooler, 1982) }\end{array}$ & $\begin{array}{l}\text { European Comission } \\
\text { Dimensions }\end{array}$ & European Comission Indicators \\
\hline $\begin{array}{l}\text { Nature of the job itself } \\
\text { Complexity of duties } \\
\text { Autonomy related to duties } \\
\text { Role inherent in duties } \\
\text { Participation in decision- } \\
\text { making related to my duties }\end{array}$ & $\begin{array}{l}\text { Time to perform duties } \\
\text { Participation in decision-making } \\
\text { concerning my duties } \\
\text { Fit between skills and type of work } \\
\text { Autonomy in performance of duties } \\
\text { Diversity of duties } \\
\text { Effectiveness at work } \\
\text { Physical requirements needed to } \\
\text { perform the duties } \\
\\
\text { Work environment (noise, lighting, } \\
\text { cleanliness, etc.) } \\
\text { Equipment and tools needed for } \\
\text { work } \\
\text { Facilities (daycare, access to } \\
\text { restaurants, parking, etc.) }\end{array}$ & $\begin{array}{l}\text { Complexity of work } \\
\text { Routine } \\
\text { Time pressure }\end{array}$ & $\begin{array}{l}\text { Skills, life-long learning and } \\
\text { career development }\end{array}$ & $\begin{array}{l}\text { - Job satisfaction among workers, taking account of } \\
\text { job characteristics, contract type and hours worked, } \\
\text { and level of qualification relative to job } \\
\text { requirement } \\
\text { - Proportion of workers advancing to higher paid } \\
\text { employment over time } \\
\text { · Low wage earners, working poor, and the } \\
\text { distribution of income } \\
\text { - Proportion of workers with medium and high } \\
\text { levels of education } \\
\text { - Proportion of workers undertaking training or } \\
\text { other forms of life-long learning } \\
\text { - Proportion of workers with basic or higher levels } \\
\text { of digital literacy } \\
\text { - Composite indicators of accidents at work - fatal } \\
\text { and serious - including costs } \\
\text { - Rates of occupational disease, including new risks } \\
\text { e.g. repetitive strain } \\
\text { - Stress levels and other difficulties concerning } \\
\text { working relationships }\end{array}$ \\
\hline
\end{tabular}


TABLE 2. Quality of work life dimensions, components, and indicators (Continued)

\begin{tabular}{|c|c|c|c|c|}
\hline $\begin{array}{l}\text { Quality of work life according } \\
\text { to Turcotte (1988) }\end{array}$ & $\begin{array}{l}\text { The } 33 \text { QWLSI domains (Martel } \\
\text { and Dupuis, 2006) }\end{array}$ & $\begin{array}{l}\text { Work structures (Kohl } \\
\text { and Shooler, 1982) }\end{array}$ & European Commission & EC Indicators \\
\hline $\begin{array}{l}\text { Psychosocial context } \\
\text { Social and emotional support } \\
\text { Respect and consideration } \\
\text { Nature of leadership } \\
\text { Identification with company } \\
\text { Satisfaction of need to belong } \\
\text { Possibility of communicating } \\
\text { Organizational context } \\
\text { Level of planning } \\
\text { Management ideology } \\
\text { Information system } \\
\text { Organizational structure } \\
\text { Training programs } \\
\text { Technical support } \\
\text { Possibilities for promotion and } \\
\text { transfer }\end{array}$ & $\begin{array}{l}\text { Feeling of belonging } \\
\text { Emotive power } \\
\text { Competitiveness } \\
\text { Relations with colleagues } \\
\text { Relations with superior } \\
\text { Relations with employer or } \\
\text { management } \\
\text { Company policies concerning leave } \\
\text { for family reasons } \\
\text { Performance of work during my } \\
\text { absence } \\
\text { Allocation of work during absence } \\
\text { of other employees } \\
\text { Possibilities for advancement } \\
\text { Transfers } \\
\text { Training and professional } \\
\text { development } \\
\text { Comments and evaluation } \\
\text { Work schedule } \\
\text { Flexible schedules } \\
\text { Clarity of my role in the } \\
\text { organization }\end{array}$ & $\begin{array}{l}\text { Feeling of belonging } \\
\text { Level of empowerment }\end{array}$ & $\begin{array}{l}\text { Work organisation and } \\
\text { work-life balance }\end{array}$ & $\begin{array}{l}\text { - Proportion of workers with flexible working } \\
\text { arrangements } \\
\text { - Opportunities for maternity and parental leave, } \\
\text { and take-up rates } \\
\text { - Scale of child-care facilities for pre-school and } \\
\text { primary school age groups }\end{array}$ \\
\hline
\end{tabular}


TABLE 2. Quality of work life dimensions, components, and indicators (Continued)

\begin{tabular}{|c|c|c|c|c|}
\hline $\begin{array}{l}\text { Quality of work life according } \\
\text { to Turcotte (1988) }\end{array}$ & $\begin{array}{l}\text { The } 33 \text { QWLSI domains (Martel } \\
\text { and Dupuis, 2006) }\end{array}$ & $\begin{array}{l}\text { Work structures (Kohl } \\
\text { and Shooler, 1982) }\end{array}$ & European Commission & EC Indicators \\
\hline & $\begin{array}{l}\text { Conflicting roles } \\
\text { Communications and information } \\
\text { Income } \\
\text { Benefits } \\
\text { Income security } \\
\text { Relations with union } \\
\text { Employee assistance resources }\end{array}$ & $\begin{array}{l}\text { Job security } \\
\text { Job stability } \\
\text { Compensation } \\
\text { Work schedule }\end{array}$ & $\begin{array}{l}\text { Flexibility and security } \\
\text { Social dialogue and worker } \\
\text { involvement } \\
\text { Social Agenda } \\
\text { Gender equality }\end{array}$ & $\begin{array}{l}\text { - The effective coverage of social protection } \\
\text { systems - in terms of breadth of eligibility and } \\
\text { level of support - for those in work, or seeking } \\
\text { work } \\
\text { · Proportion of workers with flexible working } \\
\text { arrangements - as seen by employers and workers } \\
\text { · Job losses - proportion of workers losing their job } \\
\text { through redundancies, and proportion of those } \\
\text { finding alternative employment in a given period } \\
\cdot \text { Proportion of workers changing the geographical } \\
\text { location of their work } \\
\text { - Coverage of collective agreements } \\
\text { - Proportion of workers with a financial } \\
\text { interest/participation in the firms where they are } \\
\text { employed } \\
\cdot \text { Working days lost in industrial disputes } \\
\cdot \text { - Gender pay gap, appropriately adjusted for such } \\
\text { factors as sector, occupation and age } \\
\cdot \text { Gender segregation - extent to which women and } \\
\text { men are over or under-represented in different } \\
\text { professions and sectors } \\
\cdot \text { Proportion of women and men with different } \\
\text { levels of responsibility within professions and } \\
\text { sectors, taking account of factors such as age and } \\
\text { education }\end{array}$ \\
\hline
\end{tabular}


TABLE 2. Quality of work life dimensions, components, and indicators (Continued)

\begin{tabular}{|c|c|c|c|c|}
\hline $\begin{array}{l}\text { Quality of work life according } \\
\text { to Turcotte (1988) }\end{array}$ & $\begin{array}{l}\text { The } 33 \text { QWLSI domains (Martel } \\
\text { and Dupuis, 2006) }\end{array}$ & $\begin{array}{l}\text { Work structures (Kohl } \\
\text { and Shooler, 1982) }\end{array}$ & European Commission & EC Indicators \\
\hline & & & $\begin{array}{l}\text { Inclusion and access to the } \\
\text { labour market } \\
\text { Diversity and non- } \\
\text { discrimination }\end{array}$ & $\begin{array}{l}\text { - Effective transition of young people to active life } \\
\text { · Employment and long-term unemployment rates } \\
\text { by age, educational level, region } \\
\text { · Labour market bottlenecks and mobility between } \\
\text { sectors and occupations } \\
\text { · Employment rates and pay gaps of older workers } \\
\text { compared with average } \\
\text { · Employment rates and pay gaps of persons with } \\
\text { disabilities, and persons from ethnic minorities - } \\
\text { compared with average } \\
\text { - Information on the existence of labour market } \\
\text { complaints procedures, and of successful outcomes } \\
\text { · Average hourly productivity per worker } \\
\text { - Average annual output per worker } \\
\text { - Average annual living standards per head of } \\
\text { population - taking account of the rate of } \\
\text { employment and the dependency ratio }\end{array}$ \\
\hline
\end{tabular}


An analysis of Table 2 reveals the importance of aspects that we have labelled as the Social Agenda. This Social Agenda is clearly linked to the Lisbon Strategy. It includes productivity growth in the Overall work performance dimension or other aspects that are not included in the academic definitions. In other words, almost all the indicators defined in the EC alternative are objectives measurements, while the main focus of the academic definitions of QWL is individuals' perceptions of their feelings and environment.

Therefore, as expected, the EC definition of QWL includes the main axes and even the spirit of the academic literature, but is clearly oriented to a strategic, higher goal. In the next section we make a proposal that tries to embrace both the policy-oriented approach to QWL and the more academic perspective.

\section{QUALITY OF LIFE AND QUALITY OF WORK. OBJECTIVE AND SUBJECTIVE MEASUREMENTS OF WELL-BEING. DEFINING A PROPOSAL FOR SPAIN.}

As we have already seen, the EC proposal only deals superficially with the subjective perceptions of workers. An important part of our research included devising a framework for analysing QWL in Spain. This was attained by developing specific indicators. We wanted to take advantage of the institutional framework offered by the EC. However, we also wanted to include the subjective perceptions of workers in most of the defined areas. In recent years, a survey on the quality of work life has been carried out by the Spanish Ministry of Labour and Social Affairs.

Consequently, our proposal includes both objective measurements and the subjective perceptions of individuals. We use the two main axes of the EC proposal: the micro (job characteristics) and the macro (work and labour market context). Based on the 10 dimensions and 30 concepts defined by the EC, we list up to 75 measurements. These come from objective measurements and subjective perceptions gathered from the quality of work life survey.

To avoid repetition of the dimensions and concepts already displayed in Table 2, the following pages list the dimensions, the chosen indicators and availability in terms of the source, time, geography, sectors, professional categories and even the firm's size.

\section{DIMENSION: 1. Intrinsic job quality}

CONCEPT (C): job satisfaction among workers, taking account of job characteristics, contract type, hours worked and the level of qualification relative to job requirements

INDICATORS-EC (IEC): satisfaction with type of work in present job; skills needed for current job provided by formal training or education; the possession of skills or qualifications to do a more demanding job than the current one (overqualified)

INDICATORS-SPAIN (IS): workers degree of satisfaction (Source [S]: Quality of Work Life Survey [ECVT]. Availability [Av]: region, sector, firm size and professional rate, 2001-2004); total labor cost (S: Labor Status Survey, Labour Ministry. Av: region and sector. 2001-2004); average earning per worker per month (S: Salary Structure Survey, Av: region, sector, firm size and professional rate, 2002).

C: proportion of workers advancing to higher paid employment over time IEC: current net monthly wage 
IS: interanual increase in total labor cost (S: Labor Status Survey, Labour Ministry; Av: region and sector. 2001-2004)

C: low wage earners, working poor, and the distribution of income

IEC: proportion of employees earning less than $60 \%$ of median income; is the household able to make ends meet?; income distribution as measured by the S80/S20 income quantile ratio

IS: proportion of households with earnings (S: Continuous Survey of Family Budgets, Av: region, 2001-2004); median of households' net earnings (S: ECVT. Av: region, sector, firm size and professional rate, 2001-2004)

\section{DIMENSION: 2. Skills, life-long learning and career development}

C: proportion of workers with medium and high levels of education

IEC: persons in employment with medium and high educational attainment level (ISCED) as a percentage of the employed population

IS: workers classified by education: average number of years in education (S: Bancaja: "El Capital Humano en España”, Av: region and sector, 2002); workers classified by education: proportion of active workers with higher education (S: Bancaja: “El Capital Humano en España”, Av: region and sector, 2002); active population classified by educational level: average number of years in education (S: Active Population Survey EPA, Av: region, 2001-2004); workers classified by education: proportion of active workers with higher education (S: EPA, Av: region, 2001-2004); proportion of workers with higher education (S: ECVT; Av: region, sector, firm size and professional rate, 20012004)

C: proportion of workers undertaking training or other forms of life-long learning

IEC: participation rate in education and training as defined by the percentage of the population participating in education and training by sex, age groups (25-34, 35-44, and 45-64 years old) and working status (employed, unemployed, inactive); percentage of the population aged 25-64 participating in education and training, by sex; percentage of workforce participating in job-related training, by sex (some doubts about the notion of workforce)

IS: occupational training course: finished courses per 10.000 workers (S: Labor Ministry Yearbook MTAS, Av: region and sector, 2001-2003); occupational training course: students per 100 workers (S: Labor Ministry Yearbook MTAS, Av: region and sector, 2001-2003); proportion of workers who have finished training courses (S: ECVT, Av: region, sector, firm size and professional rate, 2001-2004); proportion of workers who finished useful training courses (S: ECVT, Av: region, sector, firm size and professional rate, 2001-2004); training days financed by the firm (S: ECVT, Av: region, sector, firm size and professional rate, 2001-2004)

C: proportion of workers with basic or higher levels of digital literacy

IEC: currently not entirely available

IS: currently not entirely available

\section{DIMENSION: 3. Gender equality}

C: gender pay gap, appropriately adjusted for such factors as sector, occupation and age

IEC: ratio of women's hourly earnings index to men's for paid employees at work 15+hours by job content and education

IS: average earning ratio (women/men) (S: ECVT, Av: region, sector, firm size and professional rate, 2001-2004); salary earnings: gender differences (S: Salary Structure Survey, Av: region, sector and professional rate, 2002)

C: gender segregation - extent to which women and men are over or under-represented in different professions and sectors

IEC: the average national proportion of employment for women and men applied to employment in each sector/occupation. The differences are added and related to total employment to obtain a gender imbalance figure. 
IS: proportion of women workers, classified by sector and firm size (S: Labor Status Survey. MTAS, Av: sector and firm size, 2001-2004); activity rate: gender differences (S: EPA, Av: region, 20012004); unemployment rate: gender differences (S: EPA, Av: region, 2001-2004)

C: proportion of women and men with different levels of responsibility within professions and sectors, taking account of factors such as age and education

IEC: employment of women and men, by level of responsibility within firms and by sector (adjustment for age and education); job status (supervisory, intermediate, non-supervisory) by occupation or industry.

IS: proportion of women working as member of the board of a firm in comparison with the proportion of men on the board (S: ECVT, Av: region, sector, firm size and professional rate, 2001-2004)

\section{DIMENSION: 4. Health and safety at work}

C: composite indicators of accidents at work - fatal and serious - including costs; total and mean number of days lost due to accidents at work, by sex; occupational diseases, by sex; rates of occupational disease, including new risks e.g. repetitive strain injury

IEC: the incidence rate, defined as the number of accidents at work per 100,000 persons in employment, by sex, calculated as: [number of accidents (fatal or non-fatal) / number of employed persons in the studied population] x 100 000; health problems related to making repetitive movements; working at very high speed and its effects on health

IS: accidents at different work rates (S: Labor Accidents at Work. MTAS, Av: region, sector, firm size and professional rate, 2001-2004)

C: stress levels and other difficulties concerning working relationships

IEC: working to tight deadlines and its effects on health

IS: proportion of workers who consider that they have to do physical work (S: ECVT, Av: region, sector, firm size and professional rate, 2001-2004); proportion of workers who consider that their work is stressful (S: ECVT, Av: region, sector, firm size and professional rate, 2001-2004); proportion of workers who consider that their work is dangerous (S: ECVT, Av: region, sector, firm size and professional rate, 2001-2004); proportion of workers who consider that their work is developed in a satisfactory environment (S: ECVT, Av: region, sector, firm size and professional rate, 2001-2004); proportion of workers who consider that their work is satisfactory in hygenic terms (S: ECVT, Av: region, sector, firm size and professional rate, 2001-2004); proportion of workers who are satisfied with the safety measures (S: ECVT, Av: region, sector, firm size and professional rate, 2001-2004)

\section{DIMENSION: 5. Flexibility and security}

C: the effective coverage of social protection systems - in terms of breadth of eligibility and level of support - for those in work, or seeking work

IEC: coverage of the employed by social insurance, as measured by the total net social/social insurance receipts in the year prior to the interview (as part of income)

IS: coverage of the employed by social insurance (S: MTAS e INEM, Av: region, 2001-2004); beneficiaries of assistance insurance (S: MTAS and INEM, Av: Region. 2001-2004); benefits for retired people (S: MTAS e INEM Av: region, 2001-2004]; average amount of benefits (S: MTAS and INEM, Av: Region. 2001-2004)

C: proportion of workers with flexible working arrangements - as seen by employers and workers IEC: satisfaction with working time in present job; type of employment contract, by categories: permanent, fixed-term or short-term, casual work with no contract, some other working arrangement; full-time/part-time.

IS: salary differences between permanent and temporary contracts (S: Salary Structure Survey. Av: region, 2002); proportion of workers with permanent contracts (S: ECVT, Av: region, sector, firm size and professional rate, 2001-2004); proportion of workers with permanent contracts and undesired part time jobs (S: ECVT, Av: region, sector, firm size and professional rate, 2001-2004)

C: job losses - proportion of workers losing their job through redundancies; proportion of those finding alternative employment in a given period

IEC: reason for leaving a previous job; main reason for leaving last job or business.

IS: unemployment rate (S: EPA, Av: region, 2001-2004) 
$\mathrm{C}$ : proportion of workers changing the geographical location of their work

IEC: data available through Eurostat but in need of analysis and presentation

IS: not available

\section{DIMENSION: 6. Inclusion and access to the labour market}

C: Effective transition of young people to active life

IEC: Activity rate 15-24 as a proportion of the population of 15-24; youth unemployment ratio: unemployed aged 15-24 as a percentage of the population aged 15-24

IS: unemployment rate of young people (15-25) (S: EPA, Av: region, 2001-2004); employment rate of young people (15-25) (S: EPA, Av: region, 2001-2004)

C: employment and long-term unemployment rates by age, educational level, region

IEC: employment rate by main age group (15-24, 25-54, 55-64, 15-64) and educational attainment

levels (ISCED: high, medium and low); total long-term unemployment rate

IS: proportion of long-term unemployed workers (S: EPA, Av: region, 2001-2004)

C: labour market bottlenecks and mobility between sectors and occupations

IEC: none currently available; employed in current and previous job; sector of current and previous job

IS: vacancies / unemployed workers. (S: INEM, Av: region and professional rate, 2001-2004)

\section{DIMENSION: 7. Work organisation and work-life balance}

C: proportion of workers with flexible working arrangements

IEC: proportion of employees with flexible working arrangements (flexible hours, annualised hours contract, on-call work) out of total employees, by sex; number of employees working involuntary parttime as a percentage of total number of employees

IS: proportion of workers with part time contracts (S: EPA, Av: region, 2001-2004); proportion of workers with temporary contracts, per region (S: EPA, Av: region, 2001-2004); proportion of workers with temporary contracts, per sector (S: EPA, Av: sector, 2001-2004); proportion of workers with parttime jobs because they have not found a permanent job (S: ECVT, Av: region, sector, firm size and professional rate, 2001-2004); proportion of workers with part-time jobs because they are not willing to take on a permanent job (S: ECVT, Av: region, sector, firm size and professional rate, 2001-2004)

C: opportunities for maternity and paternity leave, and take-up rates; scale of child-care facilities for pre-school and primary school age groups

IEC: employed men and women on parental leave (paid and unpaid) as a proportion of all employed parents; allocation of parental leave between employed men and women as a proportion of all parental leave; children cared for (other than by the family) as a proportion of all children in the same age group. Broken down by before the noncompulsory preschool system, in noncompulsory or equivalent preschool system and compulsory primary education

IS: subsidy for infant care per 1,000 inhabitants (S: Labor Ministry Yearbook MTAS, Av: region, 2001-2004); infant services per 100,000 inhabitants (S: Labor Ministry Yearbook MTAS, Av: region, 2001-2004); primary health care per 1,000 inhabitants (S: Labor Ministry Yearbook MTAS, Av: region, 2001-2004); proportion of workers whose firms offer subsidies for nurseries (S: ECVT, Av: region, sector, firm size and professional rate, 2001-2004); proportion of workers whose firms offer subsidies for housing (S: ECVT, Av: region, sector, firm size and professional rate, 2001-2004); proportion of workers whose firms offer subsidies for life long learning (S: ECVT, Av: region, sector, firm size and professional rate, 2001-2004); proportion of workers whose firms offer canteen services (S: ECVT, Av: region, sector, firm size and professional rate, 2001-2004); proportion of workers whose firms offer pension plans (S: ECVT, Av: region, sector, firm size and professional rate, 2001-2004), Proportion of workers whose firms offer other services (S: ECVT, Av: region, sector, firm size and professional rate, 2001-2004) 


\section{DIMENSION: 8. Social dialogue and worker involvement}

C: coverage of collective agreements

IEC: none currently available

IS: proportion of workers with collective agreements (S: Labor Ministry Yearbook MTAS and EPA Av: region, sector and professional rate, 2001-2003); proportion of workers employed in firms without any structure for conducting collective negotiations (S: ECVT, Av: region, sector, firm size and professional rate. 2001-2004); ratio of workers with a firm-level of collective agreement (S: ECVT, Av: region, sector, firm size and professional rate, 2001-2004)

C: proportion of workers with a financial interest/participation in the firms where they are employed IEC: percentage of business units with more than 200 employees in each country using financial participation schemes

IS: proportion of workers whose salary partly depends on the firm’s profits (S: ECVT, Av: region, sector, firm size and professional rate, 2001-2004)

C: working days lost in industrial disputes

IEC: no. of working days lost (1000)

IS: ratio of lost days per strikes over working days (S: Labor Ministry Yearbook MTAS, Av: region and sector, 2001-2003)

\section{DIMENSION: 9. Diversity and non-discrimination}

C: employment rates and pay gaps of older workers compared with average

IEC: total net monthly wages

IS: activity rate for workers older than 55 (S: EPA, Av: region. 2001-2004); unemployment rate of older workers (older than 55) (S: EPA, Av: Region. 2001-2004); average earnings per worker (S: Salary Structure Survey, Av: region and sector, 2002)

C: employment rates and pay gaps of persons with disabilities, and persons from ethnic minorities compared with average

IEC: none currently available but some employment data is available concerning non-nationals IS: earnings differentials by nationality (S: Salary Structure Survey, Av: sector and professional rate, 2002); ratio of social security systems enroled in by workers over total potential workers (S: Seguridad Social e INE [Padrón], Av: region, 2001-2004); proportion of workers enroled in the social security system (S: Seguridad Social, Av: region, 2001-2004); foreigners: ratio of foreigners working in the cleaning regime (S: Seguridad Social, Av: region, 2001-2004)

C: information on the existence of labour market complaints procedures, and of successful outcomes IEC: none currently available

IS: not available

\section{DIMENSION: 10. Overall work performance}

C: average hourly productivity per worker

IEC: average productivity per hour worked, calculated as the GDP divided by the total number of hours worked during the year

IS: added value per worked hour (measured in constant euros) (S: MTAS e INE, Av: region and sector, 2001-2004)

C: average annual output per worker

IEC: annual labour productivity, calculated as GDP per person employed; GDP per head of population in purchasing power parities

IS: value added per worker (measured in constant euros) (S: MTAS and INE, Av: region and sector, 2001-2004)

C: average annual living standards per head of population - taking account of the rate of employment and the dependency ratio 
IEC: economic dependency ratio, calculated as aged 15+unemployed people as a percentage of total employment

IS: value added per capita (S: INE, Av: region and sector, 2001-2004); economic dependence ratio (nonworkers over 15 / total employment) (S: INE and EPA, Av: region, 2001-2004)

\section{CONCLUSIONS}

In this paper we have analysed the similarities between the academic and the institutional approaches to defining QWL. We have seen how almost all the indicators defined in the EC alternative are objectives measurements, while the main focus of the academic definitions of QWL is individuals' perceptions of their feelings and environment.

We have used the the quality of work life survey, carried out by the Spanish Ministry of Labour and Social Affairs, to define a framework that can combine the EC institutional definition of QWL, which is useful for policy makers, with the academic definition, which accounts for the subjective perceptions of employees.

The 10 dimensions and 30 concepts of the EC are included in 75 measurements, which are based on objective measurements and the quality of work life survey.

We believe that the academic position can enrich the knowledge environment of the policymakers, thus enabling them to make better decisions.

\section{REFERENCES}

Dupuis, G., M.-C. Taillefer, A.-M. Etienne, O. Fontaine, O. S. Boivin and A. Von Turk: 2000, 'Measurement of quality of life in cardiac rehabilitation', in J. Jobin F. Maltais and P. Leblanc (eds.), Advances in cardiopulmonary rehabilitation (pp. 247-273, Human Kinetics Publishers, Champaign).

Kohl, M. L. and C. Schooler: 1982, 'Job conditions and personality: A longitudinal assessment of reciprocal effects', American Journal of Sociology, 87, 1257-1286.

Marcel, J. P. and Dupuis, G.: 2006, 'Quality of work life: theoretical and methodological problems, and presentation of a new model and measuring instrument', Social Indicators Research, 77, 333-368.

Seashore, S. E.: 1975, 'Defining and measuring the quality of working life', in L. E. Davis and A. B. Cherns (eds.), The Quality of Working Life (pp. 105-118, Free Press, New York), .

Turcotte, P. R.: 1988, QVT: La Qualite de Vie au Travail: Une Voie vers l'Excellence (Agence d'ARC, Montreal). 